\title{
Tingkah Laku dan Kemunculan Hiu Paus (Rhincodon typus, Smith 1828) di Pantai Bentar Probolinggo
}

\author{
Puspa Kapinangasih*, Diah Permata Wijayanti, Agus Sabdono \\ Departemen IImu Kelautan, Fakultas Perikanan dan IImu Kelautan, Universitas Diponegoro \\ JI. Prof.H.Soedarto S.H, Tembalang,Semarang, Jawa Tengah 50275 Indonesia \\ ${ }^{*}$ Corresponding author, e-mail : kapinangasihpuspa@gmail.com
}

\begin{abstract}
ABSTRAK : Hiu Paus diketahui muncul di Pantai Bentar dari bulan Desember hingga Maret. Kemunculan Hiu Paus diduga berhubungn dengan aktivitas makan. Fenomena ini dimanfaatkan oleh masyarakat sekitar Pantai Bentar untuk menarik kedatangan wisatawan. Kondisi tersebut berpotensi menimbulkan dampak negatif bagi Hiu Paus. Penelitian ini bertujuan untuk mengetahui lokasi kemunculan Hiu Paus di Pantai Bentar serta perubahan tingkah laku Hiu Paus saat kegiatan wisata berlangsung. Penelitian dilakukan pada bulan Maret 2021 menggunakan metode observasi langsung dengan melakukan pengamatan di lokasi yang diduga menjadi tempat kemunculan Hiu Paus. Data tambahan diperoleh dari hasil wawancara dengan pengelola dan pemandu wisata. Lokasi kemunculan dicatat menggunakan GPS. Total lokasi kemunculan yang ditemukan berjumlah 9 lokasi yang tersebar di Perairan Gending, yaitu di bagian barat dan timur Pantai Bentar. Kemunculan terbanyak berada di timur Pantai Bentar. Hal ini karena wilayah tersebut dekat dengan bagan dan menjadi wilayah pelayaran nelayan Ikan Teri yang merupakan makanan Hiu Paus. Hiu Paus yang ditemukan berjumlah 9 ekor. Tingkah laku Hiu Paus yang ditemukan ketika aktivitas wisata berlangsung, yaitu perubahan secara perlahan seperti menyelam dan mendekat secara perlahan, perubahan mendadak seperti menjauh secara mendadak, perubahan secara tajam seperti menjauh secara tajam dan tidak merespon. Faktor yang mempengaruhi perubahan tingkah laku diduga karena adanya aktivitas yang dilakukan oleh manusia seperti berenang, mengejar Hiu Paus, melihat dari kapal, pelayaran kapal dan pemberian pakan. Hasil dari penelitian ini diharapkan dapat memberi masukan dalam pengelolaan wisata Hiu Paus Pantai Bentar.
\end{abstract}

Kata kunci: Rhincodon typus; Pantai Bentar; Interaksi; Perubahan Tingkah Laku.

\section{Beharvior Of Whale Shark (Rhincodon typus) In Tourism Location Bentar Beach Prolinggo}

ABSTRACT : Whale sharks are known to appear at Bentar Beach from December to March. The appearance of whale sharks is thought to be related to feeding activities. This phenomenon is used by the community around Bentar Beach to attract tourist arrivals. This condition has the potential to have a negative impact on the whale sharks. This study aims to determine the location of the appearance of whale sharks on Bentar Beach and changes in whale shark behavior during tourism activities. The study was conducted in March 2021 using the direct observation method by making observations at the location suspected to be the place where the Whale Shark appeared. Additional data obtained from interviews with managers and tour guides. The location of occurrence is recorded using GPS. The total location of the emergence found was 9 locations scattered in Gending Waters, namely in the west and east of Bentar Beach. Most occurrences are in the east of Bentar Beach. This is because the area is close to Bagan and is a shipping area for Anchovy fishermen which are the food for whale sharks. There were 9 whale sharks observed. Whale Shark behavior found during tourist activities, namely slow changes such as diving and approaching slowly, sudden changes such as moving away suddenly, sharp changes such as moving away sharply and not responding. Factors that influence behavior change are thought to be due to activities carried out by humans such as swimming, chasing whale sharks, watching from ships, ship sailing and feeding. The results of this study are expected to provide input in the management of Whale Shark tourism in Bentar Beach.

Keywords: Rhincodon typus; Bentar Beach; Interaction; Behavior Change

\section{PENDAHULUAN}

Probolinggo terletak di wilayah strategis dan memiliki potensi wisata dengan sumber daya alam yang melimpah (Anggraeni et al., 2020). Sumber daya alam yang menjadi potensi wisata dapat 
dijumpai di sekitar Pantai Bentar, Kabupaten Probolinggo (Haryanti dan Evira, 2018). Potensi wisata yang dimiliki Pantai Bentar berupa keindahan pantai, wahana permainan air dan keindahan hutan mangrove (Prasetyo et al., 2019) serta kemunculan Hiu Paus yang terjadi setiap tahun secara musiman (Sakuntala et al., 2016). Kemunculan Hiu Paus di Pantai Bentar, Probolinggo dapat dijumpai pada bulan Desember - Maret (Syah et al., 2018) setiap pagi hingga sore hari (Kamal et al., 2016). Kemunculannya diketahui berkaitan dengan kondisi lingkungan sekitar dan produktivitas yang tinggi, seperti tersedianya zooplankton serta larva yang melimpah (Fox et al., 2013).

Kemunculan Hiu Paus di wilayah ini diduga dipengaruhi oleh faktor sebaran klorofil-a sebagai pemicu kemunculan organisme planktonik yang menjadi pakan Hiu Paus serta persebaran arus permukaan sebagai persebaran klorofil-a (Sakuntala et al., 2016). Kemunculan Hiu Paus di Pantai Bentar dimanfaatkan oleh masyarakat sekitar untuk menarik kedatangan wisatawan guna meningkatkan kondisi sosial dan ekonomi masyarakat sekitar (Haryanti dan Evira, 2018). Kondisi tersebut dapat menimbulkan dampak negatif bagi kelangsungan hidup Hiu Paus dan lingkungan sekitar. Dampak negatif muncul ketika Hiu Paus berinteraksi dengan wisatawan. Perubahan alur kapal wisata ketika membawa para wisatawan berpotensi mengganggu kelangsungan hidup Hiu Paus. Sebagai contoh Hiu Paus dapat terluka ketika tertabrak kapal yang berlayar membawa wisatawan. Perilaku wisatawan yang secara bebas menunggangi atau memegang Hiu Paus juga dapat membuat Hiu Paus tidak nyaman sehingga melakukan pertahanan diri berupa perubahan tingkah laku dengan mengubah arah renang atau menghempaskan ekor ke wisatawan yang berada di sekitarnya serta menunjukkan perubahan lainnya (Handoko et al., 2017).

Kegiatan wisata yang dilakukan di Pantai Bentar, Probolinggo, Jawa Timur mengalami peningkatan jumlah pengunjung setiap tahunnya (Detiknews, 2019). Kegiatan wisata Hiu Paus ini jika dilaksanakan tidak sesuai dengan SOP (Standar Operasional Prosedur) interaksi manusia dengan Hiu Paus akan menyebabkan keberadaan Hiu Paus semakin terancam. Menurut KKP (2014), pedoman wisata Hiu Paus sebagai berikut; dalam satu waktu tidak boleh lebih dari 7 kapal yang berlayar, kapal berhenti 30 meter dari Hiu Paus, kecepatan kapal 10 knot dengan jarak 1 mil dan 2 knot dengan jarak 50 meter dari Hiu Paus, jumlah maksimum penyelam 8 wisatawan dan 1 pemandu, pemandu masuk air terlebih dahulu, jarak wisatawan dengan Hiu Paus 3 meter dari badan dan 4 meter dari ekor, durasi melihat Hiu Paus di kapal maksimal 15 menit, durasi berinteraksi dengan penyelaman maksimal 60 menit, tidak diperbolehkan menyentuh Hiu Paus, tidak bersuara selama berinteraksi, tidak diperkenankan memberi makan, tidak mengambil gambar dengan blitz, wisatawan harus selalu mengikuti petunjuk dan arahan pemandu.

Hingga saat ini, berbagai aktivitas yang dilakukan oleh wisatawan seperti berenang di sekitar Hiu Paus, memberi makan, berenang mendekati Hiu Paus, dan menunggangi Hiu Paus masih banyak dijumpai. Hal ini diduga karena implementasi dari standar operasional prosedur wisata Hiu Paus di Pantai Bentar, Probolinggo masih belum terlaksana sepenuhnya (Syah et al., (2018). Penelitian ini dilakukan karena belum adanya studi yang mendalam tentang tingkah laku Hiu Paus di Pantai Bentar yang berhubungan dengan aktivitas wisata. Hasil penelitian yang diperoleh diharapkan dapat memberi masukan kepada pengelola wisata Hiu Paus Pantai Bentar dalam pengelolaan wisata Hiu Paus agar dapat terus lestari.

\section{MATERI DAN METODE}

Penelitian ini dilaksanakan pada bulan Maret 2021. Metode yang digunakan pengamatan langsung dan wawancara dengan pengelola dan pemandu wisata setempat yang bersedia untuk diwawancarai (Imran, 2017). Wawancara dilakukan sebanyak 3 kali dalam seminggu. Penentuan lokasi kemunculan Hiu Paus di Pantai Bentar ditentukan dari titik koordinat lokasi kemunculan Hiu Paus yang didapat melalui GPS Garmin 78s (Sakuntala et al., 2016). Titik tersebut diolah dengan menggunakan software ArcGis (Suruan et al., 2019). Pengukuran estimasi panjang tubuh Hiu Paus ditentukan dengan membandingkan ukuran Hiu Paus dengan benda lain di sekitarnya, seperti bagan, perahu dan manusia (Sadili et al., 2015). Tingkah laku Hiu Paus di Pantai Bentar diamati secara langsung dari atas kapal selama 7 hari (Noviyanti et al., 2015). Pengamatan ini dilakukan dengan cara berdiri dan mengamati dari pinggir kapal bersama dengan 6 orang pengamat lainnya. Pengamatan dilakukan dengan mengelilingi perairan sekitar Pantai Bentar untuk mengetahui apakah terdapat kemunculan Hiu Paus atau tidak, jika terdapat kemunculan Hiu Paus pengamat 
melakukan pengamatan dan pendataan terhadap perubahan tingkah lakunya. Menurut Quiros (2007), perubahan tingkah laku Hiu Paus dapat dikelompokkan berdasar beberapa variabel seperti yang disajikan pada Tabel 1 dan 2.

Tabel 1. Faktor Penyebab Perubahan Tingkah Laku Hiu Paus

\begin{tabular}{ll}
\hline \multicolumn{1}{c}{ Variabel } & \multicolumn{1}{c}{ Deskripsi } \\
\hline Pemberian Pakan & Pengunjung memberi pakan ke Hiu Paus \\
Berenang & Pengunjung berenang mendekati Hiu Paus \\
Menghalangi/Loncat & Pengunjung menghalangi Hiu Paus atau melompat pada saat masuk \\
& kedalam air \\
Mengejar & Pengunjung mengejar Hiu Paus \\
Pelayaran & Kapal mendekati lokasi kemunculan Hiu Paus \\
\hline
\end{tabular}

Tabel 2. Bentuk Perubahan Tingkah Laku Hiu Paus

\begin{tabular}{ll}
\hline \multicolumn{1}{c}{ Variabel } & \multicolumn{1}{c}{ Deskripsi } \\
\hline Tidak Respon & Hiu Paus tidak menunjukan perubahan atau tidak bereaksi terhadap \\
& interaksi yang dibuat \\
Cuaca & Keadaan cuaca mempengaruhi kemunculan Hiu Paus \\
Sedikit/Slight & Hiu Paus membuat sedikit perubahan \\
Mendadak/Flight & Hiu Paus membuat perubahan arah secara mendadak \\
Tajam/Major & Hiu Paus merubah arah secara tajam dan menyelam \\
\hline
\end{tabular}

\section{HASIL DAN PEMBAHASAN}

Kemunculan Hiu Paus pada bulan Maret 2021 berjumlah 9 titik yang tersebar di sekitar pesisir Kecamatan Gending. Lokasi kemunculan berada di sekitar dermaga Pantai Bentar, bagian timur Pantai Bentar dekat Pantai Kumalasari dan bagian barat Pantai Bentar dekat Pantai Tambaksari (Gambar 1). Jumlah kemunculan dan titik koordinat yang ditemukan setiap hari berbeda karena mengikuti kemunculan Hiu Paus ke permukaan. Titik kemunculan paling banyak ditemukan pada hari pertama, ketiga dan ketujuh, yaitu 2 titik.

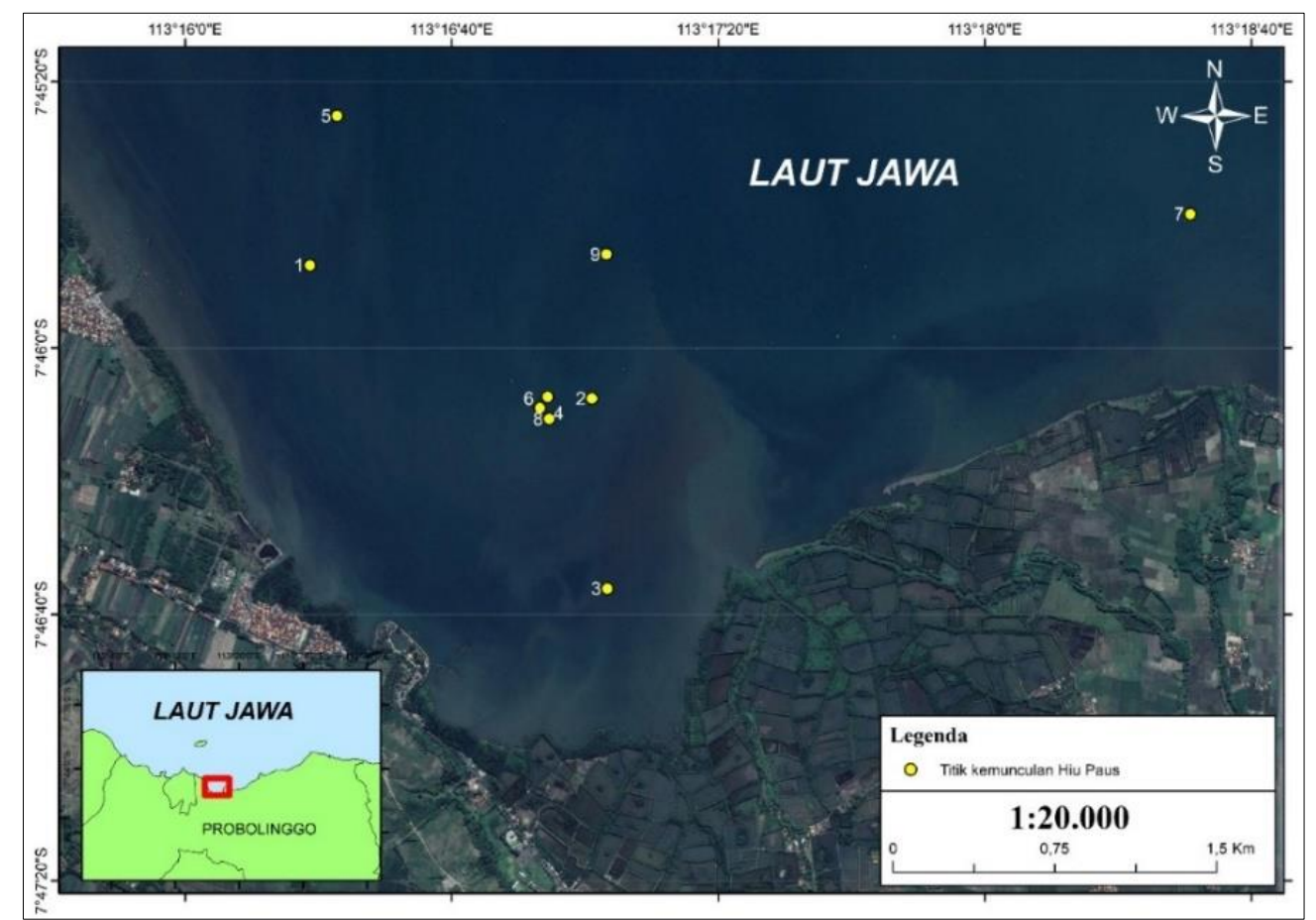

Gambar 1. Lokasi Kemunculan Hiu Paus; lingkaran kuning menunjukkan lokasi kemunculan Hiu Paus 
Hasil dari peta lokasi kemunculan Hiu Paus (Gambar 1) menunjukkan bahwa Hiu Paus paling sering muncul di lokasi nomor 2, 4, 6 dan 8 atau di sekitar bagan yang tersebar di bagian timur Pantai Bentar. Hiu Paus muncul ke permukaan diduga untuk melakukan aktivitas makan, sehingga kemunculannya banyak ditemukan di sekitar bagan yang merupakan daerah tersebarnya zooplankton serta ikan kecil sebagai makanannya. Hal ini diperkuat oleh pernyataan Motta et al. (2010) dan Syah et al. (2018), bahwa Hiu Paus muncul ke permukaan untuk mencari makan dan keberadaan zooplankton seperti, Sergestida, Copepoda, Cacing Panah/Worm, Larva Kepiting, Moluska, Krustasea, Telur Karang, dan Larva Ikan yang tersedia di permukaan merupakan sumber makanannya. Hiu Paus umumnya muncul ke permukaan untuk mencari makan, karena saat tidak mencari makan Hiu Paus lebih suka menyelam. Hal ini pun dipertegas oleh Suprapti (2015), yang menyatakan bahwa Hiu Paus sangat suka menyelam di kedalaman dan akan muncul ke permukaan jika ingin mencari makan. Hiu Paus umumnya muncul ke permukaan untuk mencari makan, karena saat tidak mencari makan Hiu Paus lebih suka menyelam. Hal ini pun dipertegas oleh Suprapti (2015), yang menyatakan bahwa Hiu Paus sangat suka menyelam di kedalaman dan akan muncul ke permukaan jika ingin mencari makan.

Tabel 3. Titik Koordinat Kemunculan Hiu Paus

\begin{tabular}{cclc}
\hline Lokasi & Hari Ke & Latitude & Longtitude \\
\hline 1 & 1 & $6^{\circ} 54^{\prime} 31.0^{\prime \prime}$ & $110^{\circ} 29^{\prime} 45.4^{\prime \prime}$ \\
2 & 1 & $6^{\circ} 54^{\prime} 32.1^{\prime \prime}$ & $110^{\circ} 29^{\prime} 50.2^{\prime \prime}$ \\
3 & 2 & $6^{\circ} 54^{\prime} 35.6^{\prime \prime}$ & $110^{\circ} 29^{\prime} 54.1^{\prime \prime}$ \\
4 & 3 & $6^{\circ} 54^{\prime} 14.9^{\prime \prime}$ & $110^{\circ} 29^{\prime} 44.7^{\prime \prime}$ \\
5 & 3 & $6^{\circ} 54^{\prime} 16.5^{\prime \prime}$ & $110^{\circ} 29^{\prime} 49.2^{\prime \prime}$ \\
6 & 4 & $6^{\circ} 54^{\prime} 19.2^{\prime \prime}$ & $110^{\circ} 29^{\prime} 53.1^{\prime \prime}$ \\
7 & 6 & $6^{\circ} 54^{\prime} 18.8^{\prime \prime}$ & $110^{\circ} 29^{\prime} 23.7^{\prime \prime}$ \\
8 & 7 & $6^{\circ} 54^{\prime} 18.4^{\prime \prime}$ & $110^{\circ} 29^{\prime} 28.5^{\prime \prime}$ \\
9 & 7 & $6^{\circ} 54^{\prime} 16.2^{\prime \prime}$ & $110^{\circ} 29^{\prime} 32.8^{\prime \prime}$ \\
\hline
\end{tabular}



Gambar 2. Persentase Kemunculan Hiu Paus berdasarkan Cuaca 
Gambar 2 menunjukkan jumlah kemunculan Hiu Paus ke permukaan tergantung dengan kondisi cuaca. Hal ini karena Hiu Paus cenderung menyukai cuaca yang mendung dan cerah berawan. Hiu Paus akan menyelam ke dasar apabila cuaca sedang terik, hal ini membuat tidak ditemukannya kemunculan Hiu Paus pada pengamatan yang dilakukan sewaktu cuaca sedang terik. Menurut Stewart (2009), dalam penelitian sebelumnya Hiu Paus menghindari suhu permukaan yang lebih tinggi dari suhu di dalam air, sebab habitat asli Hiu Paus berada di suhu yang cenderung lebih rendah dari suhu permukaan air dan cenderung menyukai perairan yang hangat dengan cuaca yang cerah berawan. Kemunculan Hiu Paus bulan Maret 2021 ini ditemukan pada siang hari pukul 11.00 WIB - 13.30 WIB dengan kondisi cuaca cerah berawan. Menurut penelitian Kamal et al. (2016), kemunculan Hiu Paus di Pantai Bentar banyak ditemukan di pagi hari hingga pagi menjelang siang, yaitu pada pukul 06.00 WIB - 11.59 WIB.

Tabel 4. Estimasi Ukuran Panjang Hiu Paus






$\begin{array}{llll}\text { Tanggal Pembanding } & \text { Estimasi Ukuran } & \text { Dokumentasi }\end{array}$

$13 / 03 / 21$

4-5 meter

$14 / 03 / 21$

Wisatawan

4 - 5 meter

$16 / 03 / 21$

Kapal Wisata

3-4 meter

$17 / 03 / 21$

5-6 meter

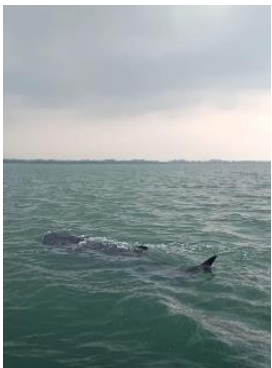

$17 / 03 / 21$

3-4 meter

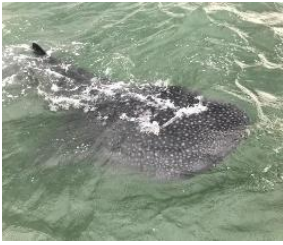

Kemunculan Hiu Paus pada 11 Maret 2021 - 17 Maret 2021 berjumlah 9 ekor. Menurut hasil wawancara dengan Bapak Samad kemunculan yang ditemukan di tahun ini pada bulan Maret lebih sedikit dibandingkan pada bulan Desember - Februari. Hasil ini sesuai dengan hasil penelitian Syah et al. (2018), yang menyatakan di tahun 2017 pada bulan Februari kemunculan Hiu Paus di Pantai Bentar mengalami peningkatan atau masuk kedalam frekuensi tertinggi, kemudian pada bulan Maret 
Tabel 5. Perubahan Tingkah Laku Hiu Paus terhadap Interaksi Manusia

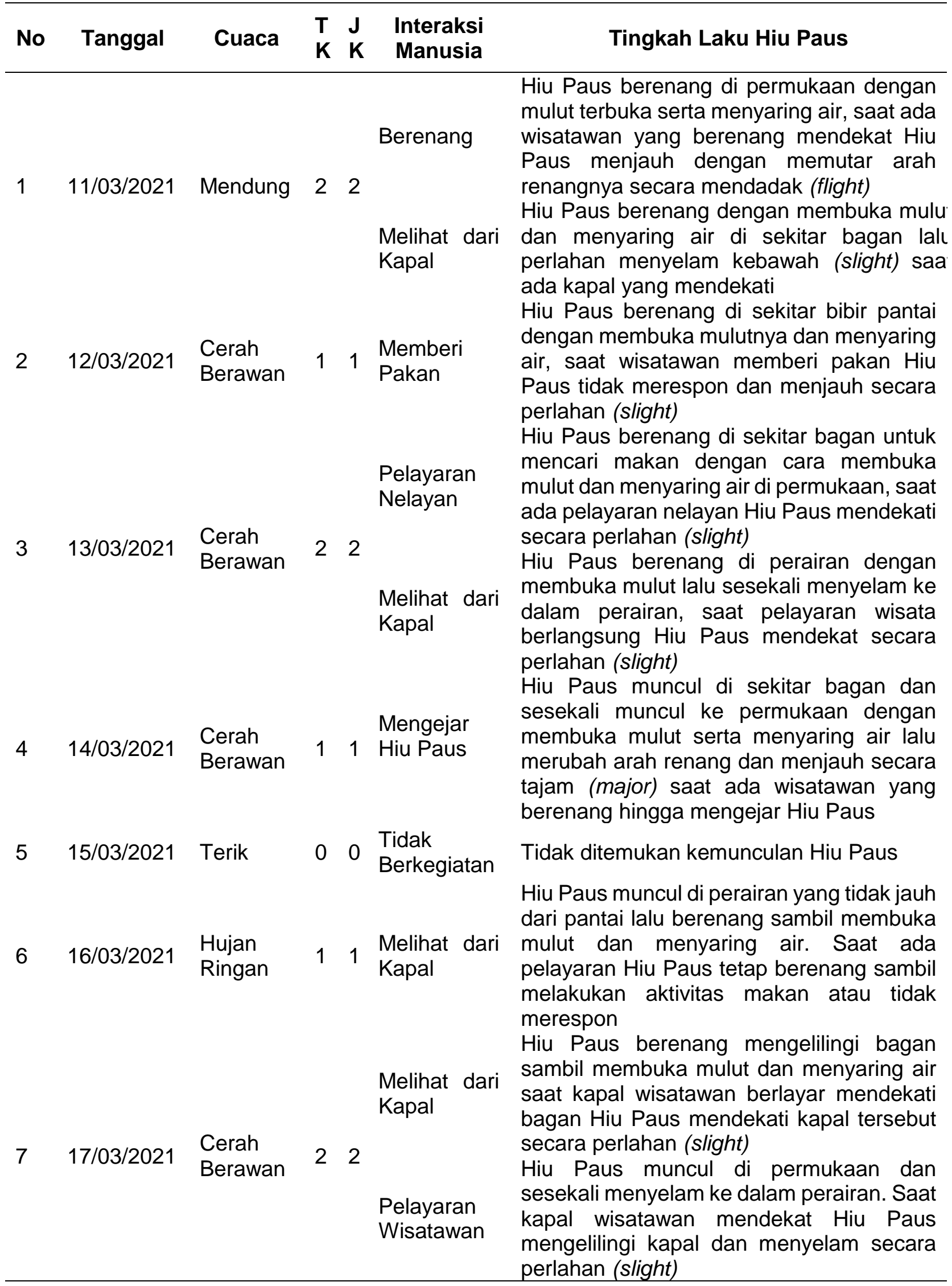


kemunculannya mengalami penurunan sehingga jumlah kemunculannya lebih sedikit. Terbatasnya jumlah Hiu Paus yang berhasil ditemukan diduga dipengaruhi oleh perbedaan waktu pengamatan (Kamal et al., 2016).

Ukuran Hiu Paus yang ditemukan sewaktu pengamatan berkisar antara 3 - 6 meter. Ukuran yang ditemukan sesuai dengan penelitian yang pernah dilakukan oleh Sakuntala et al. (2016), bahwa rata - rata ukuran Hiu Paus yang ditemukan di bulan Januari - Maret di Pantai Bentar Probolinggo berkisar antara 3 - 7 meter. Ikan ini juga ditemukan di Teluk Tomini dengan ukuran mencapai 8 meter (Rahman et al., 2017). Menurut penelitian sebelumnya yang dilakukan di Maldives oleh Perry et al. (2018), ukuran Hiu Paus yang ditemukan mencapai 18,8 meter. Hiu Paus dikatakan sebagai hewan laut yang memiliki ukuran tubuh sangat besar hingga mencapai 20 meter. Hal ini pun sesuai dengan pernyataan Toha et al. (2014).

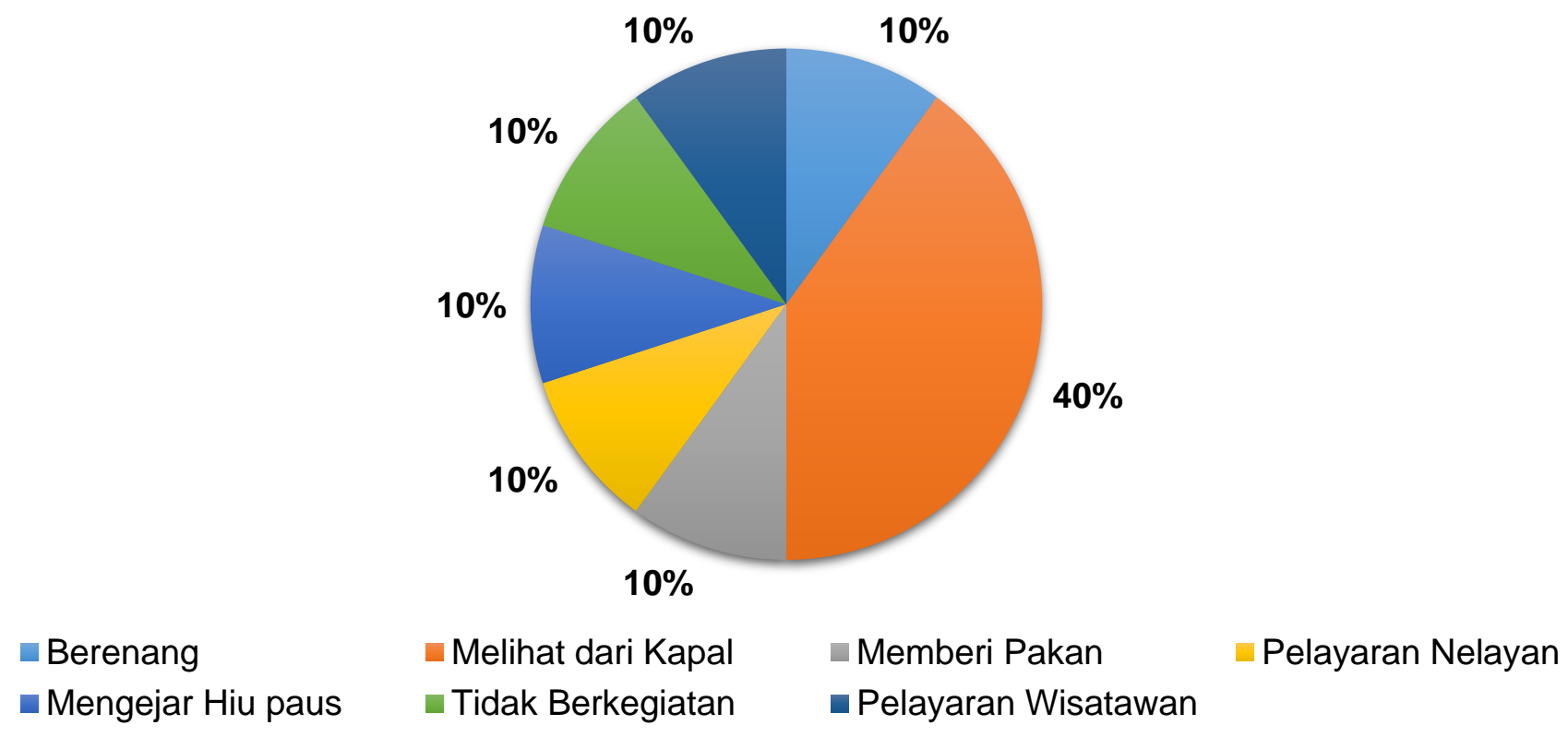

Gambar 3. Persentase Interaksi Manusia dengan Hiu Paus



-Flight $\quad$ Slight $\quad$ Mayor $\quad$ Tidak Ada $\quad$ Tidak Merespon

Gambar 4. Persentase Perubahan Tingkah Laku Hiu Paus 
Kemunculan Hiu Paus di Pantai Bentar terjadi setiap tahun secara musiman di bulan Desember Maret. Hal tersebut didukung oleh penelitian yang dilakukan oleh Kamal et al. (2016), yang menyatakan kemunculan Hiu Paus di Pantai Bentar, Probolinggo terjadi setiap tahun di bulan Desember - Maret dan menjadi potensi wisata. Kemunculan Hiu Paus di Indonesia juga terjadi di sekitar perairan Sabang, Situbondo, Bali, Nusa Tenggara, Alor, Flores, Kalimantan Timur, Gorontalo, Sulawesi Utara, Maluku dan Papua (Toha et al., 2014).

Hiu Paus di Indonesia dilindungi secara penuh sesuai dengan Keputusan Menteri Kelautan dan Perikanan No. 18 Tahun 2013 tentang penetapan status perlindungan penuh ikan Hiu Paus, sehingga pemanfaatannya sebagai objek wisata pun dibatasi. Kegiatan wisata Hiu Paus dapat ditemukan di Taman Nasional Teluk Cenderawasih dan Pantai Bentar Probolinggo. Interaksi yang dilakukan oleh wisatawan di Pantai Bentar, Probolinggo pada Maret 2021 adalah berenang dekat Hiu Paus, melihat dari kapal, memberikan pakan dengan melemparkan roti ke permukaan air, pelayaran nelayan ikan, wisatawan berenang mengejar Hiu Paus. Kegiatan yang ditemukan dalam pengamatan ini tidak jauh berbeda dengan yang ditemukan oleh Noviyanti et al. (2015), dalam penelitiannya di Pantai Bentar dtemukan kegiatan wisata berupa berenang mendekati Hiu Paus dan mengelilingi dengan kapal. Kondisi perairan di Pantai Bentar tidak mendukung adanya kegiatan snorkeling, sehingga aturan yang dapat diterapkan berupa pemberian jarak aman perahu. Hal ini sesuai dengan penelitian Imam et al. (2019), dimana SOP yang disusun di Pantai Bentar hanya menjaga jarak aman perahu tidak kurang dari 5 meter dari Hiu Paus dan tidak diperbolehkan lebih dari dua kapal wisata dalam satu pelayaran.

Interaksi antara wisatawan dan Hiu Paus jika dikelompokkan memiliki persentase yang beragam seperti terlihat pada Gambar 3. Interaksi yang sering dilakukan adalah melihat kemunculan Hiu Paus dari kapal. Pengamatan dari atas kapal ini dilakukan dengan kondisi kapal yang mesinnya mati agar tidak mengganggu Hiu Paus. Berdasarkan pengamatan selama 7 hari, ditemukan beberapa pemandu wisata yang masih tidak menerapkan SOP interaksi manusia dengan Hiu Paus. Sebagai contoh terdapat beberapa awak kapal yang tidak mematikan mesin kapal pada saat mengamati Hiu Paus agar dapat mengikuti kemana Hiu Paus tersebut berenang. Menurut Syah et al. (2018), di Pantai Bentar, Probolinggo masih banyak hal yang dilakukan tidak sesuai dengan SOP interaksi manusia dengan Hiu Paus, seperti pengamatan Hiu Paus dengan kondisi mesin kapal menyala serta penangkapan ikan yang dilakukan pada kedalaman 9 - 14 meter pada saat Hiu Paus sering muncul.

Respon yang ditunjukkan dari interaksi wisatawan dengan Hiu Paus beragam, mulai dari tidak merespon hingga perubahan tajam atau major (Tabel 5). Hiu Paus mengalami perubahan yang sangat tajam atau major seperti memutar arah renang lalu menjauh secara tajam hingga menghempaskan ekor ke wisatawan pada saat ada wisatawan yang berusaha mengejarnya dengan cara berenang. Hal ini terjadi karena Hiu Paus merasa wisatawan tersebut adalah ancamannya. Perubahan yang ditemukan ini serupa dengan perubahan yang ditemukan oleh Handoko et al. (2017), dalam penelitiannya, dimana pada saat wisatawan menunggangi atau memegang dan mengejarnya Hiu Paus akan melakukan pertahanan diri berupa penghepasan ekor. Hiu Paus juga mengalami perubahan secara mendadak atau flight seperti memutar arah renang dari barat ke timur dan menjauh secara mendadak saat ada wisatawan yang berenang dengan jarak dekat sekitar 2 meter. Hal ini karena wisatawan tidak mematuhi SOP dan Hiu Paus merasa terancam dengan jarak berenang yang terlalu dekat. Jarak berenang bersama Hiu Paus yang sesuai dengan SOP, yaitu minimal 5 meter. Hal ini juga dijelaskan dalam penelitian Imam et al., (2019), bahwa jarak aman mengamati satu ekor Hiu Paus dari badan 3 meter dan dari ekor sejauh 5 meter.

Perubahan lain dari tingkah laku Hiu Paus juga ditemukan pada saat wisatawan kapal lain memberikan pakan berupa roti (Tabel 5). Hiu Paus tidak merespon pemberian pakan itu dan tetap berenang kemudian menjauh dari kapal secara perlahan atau slight. Informasi yang didapatkan dari Bapak Samad selaku pemandu wisata setempat Hiu Paus di Pantai Bentar, Probolinggo ini tidak pernah menerima pakan yang diberikan oleh wisatawan, selain karena pakannya berupa roti juga karena Hiu Paus di wilayah tersebut sudah terbiasa mencari makan sendiri. Pernyataan ini sesuai dengan yang disampaikan oleh Toha et al. (2014), bahwa Hiu Paus memiliki sifat alamiah yaitu bermigrasi untuk mencari makan. Hiu Paus di Pantai Bentar ini mengalami perubahan arah renang secara perlahan atau slight dengan menyelam ke bawah pada saat sedang berenang dan membuka mulut serta menyaring air di permukaan saat tubuhnya hampir mengenai bagian lambung kapal. Hiu 
Paus berenang mengelilingi kapal wisatawan lalu menyelam secara perlahan atau slight saat kapal tersebut mengelilingi Hiu Paus. Hiu Paus akan mendekati kapal pelayaran nelayan dan kapal wisatawan secara perlahan atau slight apabila kapal tersebut berada di sekitar kemunculannya. Hal ini karena Hiu Paus muncul ke permukaan untuk mencari makan dan di sekitar kapal tersebut terdapat banyak ikan kecil serta plankton yang menjadi sumber makanannya.

Menurut Cruz et al. (2013), Hiu Paus merupakan jenis hewan yang hidup secara soliter, namun di beberapa lokasi cenderung berkelompok. Secara naluri alaminya Hiu Paus berpindah dari satu tempat ke tempat lain untuk mencari makan dan melanjutkan siklus hidupnya. Hiu Paus bersifat jinak sehingga kemunculannya dimanfaatkan menjadi objek wisata. Hewan ini memiliki kebiasaan untuk bermigrasi dari satu tempat ke tempat lainnya untuk mencari makan dengan mengikuti keberadaan plankton pada suatu perairan (Toha et al., 2014). Kegiatan pemberian pakan oleh wisatawan seperti yang ada di beberapa tempat wisata Hiu Paus dapat mempengaruhi hingga merubah sifat alami Hiu Paus. Hal ini karena kebiasaan pemberian pakan ini dapat membuat Hiu Paus bergantung pada wisatawan. Pernyataan ini pun sesuai dengan penelitian yang dilakukan oleh Handoko et al. (2017), berdasarkan hasil penanda akustik kemunculan Hiu Paus di perairan Botubarani dipengaruhi oleh pemberian makan berupa kepala dan kulit udang Vaname (Litopenaeus vannamel) melalui aktivitas wisata. Perilaku beberapa individu Hiu Paus ini telah diamati dan didata secara berkala. Menurut penelitian Sadili et al. (2015), kegiatan wisata Hiu Paus di Taman Nasional Teluk Cenderawasih dapat ditemukan setiap tahun. Pelaksanaan kegiatan wisatanya pun menerapkan SOP Wisata Hiu Paus sebagai pedoman wisata. Kemunculan Hiu Paus di negara lain juga menjadi potensi wisata, contohnya di Seychelles, Afrika Timur. Pernyataan ini pun didukung oleh penelitian yang dilakukan Rowat dan Udo (2007), karena kemunculan Hiu Paus yang terjadi secara teratur di Seychelles dijadikan sebagai sumberdaya ekowisata yang potensial. Menurut penelitian yang dilakukan oleh Imam et al. (2019), kegiatan wisata Hiu Paus yang dilakukan di Pantai Kwatisore, Nabire adalah snorkeling bersama Hiu Paus dengan syarat harus memiliki lisensi menyelam dan harus menjaga jarak minimal 3 meter dari Hiu Paus. Pengunjung di lokasi ini juga di informasikan tidak boleh menyentuh dan memberi makan Hiu Paus serta berfoto dengan menggunakan flash. Kegiatan wisata Hiu Paus tidak hanya dilakukan di Indonesia melainkan di beberapa negara lain, seperti Australia dan Filipina. Menurut Davis dan Tisdell (1999), kemunculan Hiu Paus yang berada di Laut Ningaloo Australia Barat menjadi potensi wisata karena di wilayah tersebut wisatawan dapat berenang bersama dengan Hiu Paus dengan jarak yang dekat. Menurut Quiros (2007), kegiatan wisata Hiu Paus di Donsol Filipina pun menarik perhatian wisatawan karena dapat melihat Hiu Paus dari dekat serta dapat menyelam dan berenang dengan Hiu Paus.

\section{KESIMPULAN}

Berdasarkan hasil yang didapatkan, maka dapat disimpulkan bahwa terdapat 9 titik kemunculan Hiu Paus di Perairan sekitar Pantai Bentar, Kecamatan Gending, Kabupaten Probolinggo, Jawa Timur. Respon tingkah laku Hiu Paus yang terjadi saat adanya interaksi dengan manusia yaitu perubahan arah berenang dari timur ke barat hingga menyelam secara perlahan (slight) pada saat wisatawan mengamati dari kapal, perubahan arah renang secara mendadak (flight) pada saat wisatawan berenang didekatnya, tidak merespon dan tetap berenang dengan arah yang sama saat wisatawan memberi pakan roti, mendekat secara perlahan (slight) saat terdapat pelayaran wisata maupun nelayan, merubah arah renang dan menjauh secara tajam (major) saat wisatawan berenang mengejar Hiu Paus.

\section{UCAPAN TERIMAKASIH}

Penulis menyampaikan terimakasih kepada dua orang reviewer yang telah memberikan saran perbaikan untuk kesempurnaan artikel. Penulis mengucapkan terimakasih kepada Theodorus Otniel yang telah membantu selama pengambilan data. Penulis juga menyampaikan penghargaan kepada pengelola Wisata Pantai Bentar serta para pemandu wisata yang telah bersedia menerima wawancara. 


\section{DAFTAR PUSTAKA}

Anggraeni S.M., I Wayan S., \& Kristiawan. 2020. Arsitektur Kolonial di Heerenstraat dalam Upaya Pelestarian Warisan Budaya Kota Probolinggo, Jawa Timur. Journal of Arts and Humanities, 25(2):200-208.

Cruz, F.A., Shoou-Jeng, J., Kwang-Ming, L., Hua-Hsun, H., \& Tzu-Chi, H. 2013. A Preliminary Study on The Feasibility of Whale Shark (Rhincodon typus) Ecotourism in Taiwan. Elsevier; Ocean \& Coastal Management., 80:100-106.

Davis, D., \& Tisdell, C. 1999. Tourist Levies and Willingness to Pay for a Whale Shark Experience. Tourism Economics. 5(2):161-174.

Detiknews. 2019. https://news.detik.com/berita-jawa-timur/d-4838667/kemunculan-hiu-tutul-masihjadi-primadona-pengunjung-pantai-bentar-probolinggo.

Fox, S., Foisy, I., De La Parra Venegas, R., Galván Pastoriza, B.E., Graham, R.T., Hoffmayer, E.R, Holmberg, J. \& Pierce, S.J. 2013. Population Structure and Residency of Whale Sharks Rhincodon typus at Utila, Bay Islands, Honduras. Journal of Fish Biology, 1-14. DOI: 10.1111/jfb.12195.

Haryanti, T.U. \& Evira, H. 2018. Pernanan Pantai dalam Kondisi Sosial Ekonomi Masyarakat disekitar Pantai Bentar Kabupaten Probolinggo Jawa Timur. Universitas Jember., 12-16.

Imam, D., Mohammad, M.K. \& Rifka, F. 2019. Human-Whale Shark Interaction: An Inquiry into Standard Operational Procedure (SOP) for Tourist in Papua and East Java. International Conference on Life Sciences and Technology., 276: 1-14. DOI: 10.1088/1755-1315/276/ $1 / 012030$.

Imran, H.A. 2017. Peran Sampling dan Distribusi Data dalam Penelitian Komunikasi Pendekatan Kuantitatif. Jurnal Studi Komunikasi dan Media, 21(1):111-126.

IUCN. 1990. 1990 IUCN Red List of Threatened Animals. IUCN, Gland, Switzerland and Cambridge, UK. https://www.iucnredlist.org/

Handoko, K., Mahardika, R.H., Casandra, T., Urif, S., Munandar, J., Hawis, M., Beginer, S \& Sri, H. 2017. Hiu Paus Pantai Butobarani Gorontalo. Balai Pengelolaan Sumberdaya Pesisir dan Laut (BPSPL) : Makasar. $216 \mathrm{hlm}$.

Kamal, M.M., Yusli, W. \& Nenden, S.N. 2016. Habitat Conditions and Potential Food Items During the Appearance of Whale Sharks (Rhincodon typus) in Probolinggo Waters, Madura Strait, Indonesia. Qscience Proceedings. DOI: 10.5339/qproc.2016.iwsc4.27.

Motta, P.J., Michael, M., Robert, E.H., Ray, L.D., Rafael, D.L.P., Samantha, L.M., Maria, L.H., James, A.S., Kyle, R.M., Jayne, M.G., John, P.T. \& Leslie, D.Z. 2010. Feeding Anatomy, FilterFeeding Rate, and Diet of Whale Sharks Rhincodon typus During Surface Ram Filter Feeding off the Yucatan Peninsula, Mexico. Zoology, 113:199-212.

Noviyanti, N.S., Kamal, M.M. \& Wardiatno, Y. 2015. Kemunculan Hiu Paus (Rhincodon typus), di Pesisir Kabupaten Probolinggo Jawa Timur. Prosiding Simposium Hiu dan Paus di Indonesia, 115 - 119.p

Perry, C.T., Figueiredo, J., Vaudo, J.J., Hancock, J., Rees, R., \& Shivji, M. 2018. Comparing LeghtMeasurement Methods and Estimating Growth Parameters of Free-Swimming Whale Shark (Rhincodon typus) near to South Ari Atoll, Maldives. Marine and Freshwater Research, 69:14871495. DOI: 10.1071/MF17393.

Prasetyo, M.A.I., Taryono \& Mohammad, M.K. 2019. Model Permintaan Kegiatan Wisata Pantai Bentar untuk Pengelolaan Wisata Hiu Paus di Pesisir Probolinggo, Jawa Timur. Konservasi Wisata Bahari dan Perubahan Iklim : Seminar Nasional Riset Sosial Ekonomi Kelautan dan Perikanan 2018., 1-868.

Quiros, A.L. 2007. Tourist compliance to a Code of Conduct and the resulting effects on whale shark (Rhincodon typus) behavior in Donsol, Philippines. Elsevier : Fisheries Research., 84:102- 108. DOI: 10.1016/j.fishres.2006.11.017.

Rahman, A., Joni, H., Agus, A.S. \& Mujiyanto. 2017. Kajian Awal Kemunculan Hiu Paus (Rhyncodon typus, Smith 1828) di Teluk Tomini dihubungkan dengan Faktor Fisik dan Biologi Perairan. Jurnal Akuatika Indonesia. 2(2):128-136. 
Rowat, D. \& Udo, E. 2007. Seychelles : A Case Study of Community Involvement in the Development of Whale Shark Ecotourism and its Socio-Economic Impact. Elsevier: Fisheries Research, 84:109-113.

Sadili, D., Dharmadi, F., Sarmintohadi, R.I., Tania, C., Noor, B.A., Prabowo, R.H., Miasto, Y., Puspitasari, R., Terry, N., Monintja, M. \& Annisa, S. 2015. Pedoman Umum Monitoring Hiu Paus di Indonesia. Direktorat Konservasi Kawasan dan Jenis Ikan Ditjen Kelautan, Pesisir dan Pulau - Pulau Kecil Kementrian Kelautan dan Perikanan: Jakarta, 45 hlm.

Sakuntala, A.P., Oktiyas, M.L. \& Andik, I. 2016. Kajian Kemunculan (Agresi) Hiu Paus (Rhincodon typus) berdasarkan Faktor Lingkungan (SPL, Klorofil-a dan Arus Permukaan) di Perairan Kabupaten Probolinggo, Jawa Timur. Mahasiswa dan Dosen Fakultas Perikanan dan IImu Kelautan Universitas Brawijaya., 1-15.

Stewart, B.S. 2009. Movements and Habitats of Whale Sharks of East Africa: Results of Tagging Studies in 2007 \& 2008. HSWRI Technical Report. 368: 1-61.

Suprapti, D. 2015. Marine Species Conservation Coordinator. WWF Indonesia.

Suruan, S.S., Kamal, M.M., Bawole, R., Tania, C. \& Mulyadi, M.,. 2019. Sebaran Populasi Ikan Hiu Paus (Rhincodon typus, Smith 1828) di Perairan Kwatisore, Kabupaten Nabire, Provinsi Papua. Prosiding Simposiun Nasionel Hiu Pari Indonesia, 23-32.

Syah A.F., Musrifah \& Hendrik, C. 2018. Pemodelan Daerah Potensial Kemunculan Hiu Paus (Rhincodon typus) menggunakan Data Penginderaan Jauh di Perairan Probolinggo, Jawa Timur. Jurnal Penelitian Perikanan Indonesia, 24(3):209-216.

Toha, A.H.A., Madduppa, H.H., Tania, C., Noor, B.A., Widodo, N. \& Subhan, B., 2014. Hiu Paus di Taman Nasional Teluk Cenderawasih. Riset dan Monitoring. Brainy Bee: Malang., $320 \mathrm{hlm}$. 